\title{
Original Research \\ Trends in pharmacy staff's perception of patient safety in Swedish community pharmacies after re-regulation of conditions
}

\author{
Sofia KÄLVEMARK SPORRONG, Annika NORDÉN-HÄGG.
}

Received (first version): 18-Aug-2014 Accepted: 2-Dec-2014

\begin{abstract}
${ }^{*}$
Background: All changes in the regulation of pharmacies have an impact on the work carried out in pharmacies and also on patient safety, regardless of whether this is the intention or not.

Objective: To compare staff apprehension regarding some aspects of patient safety and quality in community pharmacies prior to and after the 2009 changes in regulation of the Swedish community pharmacy market. Methods: Questionnaires targeted at pharmacy staff before and after the changes in regulation (in 2008, $2011 / 12$, and 2012/13 respectively) used four identical items, making comparisons of some aspects possible. Results: All four items demonstrated a significant decrease in the first survey after the changes as compared to before. In the second survey significant differences were found on the two items representing safety climate whereas the items representing team climate and management showed no significant differences. Conclusions: The comparison carried out in this study indicates a negative effect in Swedish community pharmacies on safety and quality issues, as experienced by pharmacy staff. It is recommended that the possible effects of healthcare reforms are assessed before implementation, in order to counteract conceivable decline in factors including patient safety and working conditions.
\end{abstract}

Keywords: Pharmacies; Government Regulation; Community Pharmacy Services; Patient Safety; Attitude of Health Personnel; Sweden

\footnotetext{
Sofia KÄLVEMARK SPORRONG. Ph.D. Department of Pharmacy, University of Copenhagen. Copenhagen (Denmark).sofia.sporrong@sund.ku.dk

Annika NORDÉN-HÄGG. Ph.D. Department of Pharmacy, Uppsala University. Uppsala (Sweden). annikanordn.h@telia.com
}

\section{INTRODUCTION}

All changes in the regulation of pharmacies have an impact on the organization and work carried out in pharmacies and also on patient safety, regardless of whether this was the intention or not. It has also been suggested that regulatory changes for pharmacies often lead to increased workload for staff, with less time for counseling and advice to patients. Increased demands on financial profitability are also said to affect working conditions. $^{1}$

In July 2009 there were major changes in the regulation of the pharmacy market in Sweden, which went from a state-owned pharmacy monopoly to an open market. The purpose of this study was to examine staff apprehension regarding some aspects of patient safety and quality in community pharmacies prior to and after this reregulation.

The political rationales for the re-regulation were focused on availability to pharmacies, and ownership issues. ${ }^{2,3}$ It has resulted in e.g. an increase in the number of pharmacies (from 925 pharmacies in July 2009 to approximately 1,350 in January 2014) ${ }^{4}$, mostly in densely populated areas. ${ }^{5}$ There are now few restrictions on ownership of pharmacies. Pharmacies are today operated by a wide range of owners; including international chains, newly-established domestic chains, and individuals, including a few pharmacists, but mostly other professions. ${ }^{6}$

Patient care in pharmacies includes optimization of patients' drug therapy, achieving better patient outcomes and improving the quality of patient's lives. ${ }^{7}$ Quality and patient safety was however not in focus during the political process preceding the regulatory change. The one substantial outcome in this area was the regulation of a specialist functiona pharmacist responsible for pharmacy operations meeting quality requirements. ${ }^{8}$ The function existed prior to the reregulation but has now become regulated. ${ }^{9,10}$

Several factors impact patient safety in pharmacies, among them the working conditions for staff ${ }^{11}$ which can influence the detection of drug-drug interactions $^{12}$, pharmacists' interventions ${ }^{13,14}$ and number of dispensing errors. ${ }^{15-18}$ There are reports of increased pressure on pharmacy staff after the reregulation. In one survey $58 \%$ of respondents reported experiencing more stress, and $4 \%$ less stress, than before the reregulation. ${ }^{19}$ In another survey, the conditions regarding safe dispensing of medicines had deteriorated in comparison to the 
Table 1. Questions and dimensions derived from the SAQ Swedish Community Pharmacy version, used also in the studies carried out by the Swedish Agency for Public Management. $^{6,20,23}$

\begin{tabular}{l|l|}
\multicolumn{1}{|c|}{ Question } & \multicolumn{1}{c|}{ Dimension } \\
\hline $\begin{array}{l}\text { I would feel safe as a customer } \\
\text { here }^{\mathrm{b}}\end{array}$ & Safety Climate \\
\hline $\begin{array}{l}\text { Dispensing errors are handled in a } \\
\text { correct way at this pharmacy }\end{array}$ & Safety Climate \\
$\begin{array}{l}\text { The staff level at this pharmacy is } \\
\text { sufficient to handle the number of } \\
\text { customers }\end{array}$ & Teamwork Climate \\
$\begin{array}{l}\text { The management of this pharmacy } \\
\text { supports me in my daily work }\end{array}$ & $\begin{array}{l}\text { Perceptions } \\
\text { Management }\end{array}$ \\
\hline
\end{tabular}

The response alternatives applied in all three studies were: Disagree strongly / Disagree slightly / Neutral / Agree slightly / Agree strongly / Not applicable.

${ }^{b}$ Here implies at this pharmacy

${ }^{\mathrm{c}}$ This item is not included in the compilation carried out by the Agency, even though it was included in the survey.

situation before the re-regulation, according to $55 \%$ of the respondents, while $28 \%$ considered the conditions unaltered and $11 \%$ as improved. The work load was considered to have increased by $72 \%$ of the respondents.

However, in both surveys mentioned above the respondents were asked to compare the present situation with their former experience, thus recall bias is an obvious problem. Baseline data are scarce, but before the re-regulation a study was carried out on patient safety in Swedish pharmacies in which safety culture and the handling of quality markers such as errors were highlighted. ${ }^{20,21}$ The reuse of some items originating from this study provides an opportunity to make comparisons between the situation prior to and after the reform.

\section{METHODS}

In the study carried out prior to the reregulation, the Safety Attitude Questionnaire Swedish Community Pharmacy Version; SAQ was used. ${ }^{20}$ SAQ was developed to assess the quality of safety- and teamwork-related norms and behaviors of individual workers, in a particular setting. ${ }^{22}$ This survey was adapted to and used in Swedish community pharmacies. ${ }^{20}$ This survey includes 40 questions, aggregated into six dimensions. It is hereafter referred to as the SAQ study.
After the reregulation, two surveys were carried out by The Swedish Agency for Public Management, hereafter named the Agency studies. These surveys were mainly studying competencies and safety in drug handling after the reregulation. Four questions were derived from the SAQ study mentioned above (Personal communication, Anna Eriksson, Swedish Agency for Public Management, August 7, 2012), see Table 1.

In the SAQ study all staff members working in Swedish pharmacies, which at the time of the study in the spring of 2008 encompassed approximately 870 pharmacies, were included. All staff members listed as employed on December $1^{\text {st }} 2007$ in these pharmacies were invited to participate. A total of 7,244 questionnaires were distributed via e-mail. ${ }^{20}$

The Agency surveys were conducted in December 2011 - January 2012 and December 2012-January 2013 , respectively. They were distributed to a total of 1,500 (2012) and 2,500 (2013) randomly selected pharmacy employees. The respondents were all members of one of the two unions - The Swedish Pharmaceutical Association or Farmaciförbundet. The unions organize $>95 \%$ of the working staff in Swedish pharmacies and comprise approximately 7,500 members each. ${ }^{6,23}$ The questionnaire was distributed to 750 (2012) and 1250 (2013) members of each union, by e-mail. ${ }^{6,23}$

Differences between the results of the SAQ and Agency studies were calculated using a two-sided ttest. Significance was tested at the $5 \%$ significance level.

\section{RESULTS}

In the SAQ study the response rate was approximately $61 \%$ (4,090 respondents); $70 \%$ of the respondents were pharmacists and $26 \%$ pharmacy technicians. In the Agency studies the response rates were $63 \%$ and $60 \%$ respectively (1401 and 1519 respondents). Of these 71 and $70 \%$ were pharmacists and $27 \%$ of the respondents in both studies were pharmacy technicians. Out of the respondents in the two Agency studies $84 \%$ (both studies) had been employed in a pharmacy before July $1^{\text {st }} 2009$, i.e. before the re-regulation.

The distribution of answers is displayed in Table 2.

\begin{tabular}{|c|c|c|c|c|c|c|c|c|c|c|c|c|}
\hline & \multicolumn{3}{|c|}{$\begin{array}{l}\text { I would feel safe as a } \\
\text { customer here }(\%)\end{array}$} & \multicolumn{3}{|c|}{$\begin{array}{c}\text { Dispensing errors are } \\
\text { handled in a correct } \\
\text { way at this pharmacy } \\
(\%)\end{array}$} & \multicolumn{3}{|c|}{$\begin{array}{l}\text { The staff level at this } \\
\text { pharmacy is sufficient } \\
\text { to handle the number } \\
\text { of customers (\%) }\end{array}$} & \multicolumn{3}{|c|}{$\begin{array}{l}\text { The management of } \\
\text { this pharmacy } \\
\text { supports me in my } \\
\text { daily work }(\%)^{1}\end{array}$} \\
\hline & $\begin{array}{l}\text { Prior } \\
\text { reform } \\
2008\end{array}$ & $\begin{array}{l}\text { Post } \\
\text { reform } \\
2012\end{array}$ & $\begin{array}{l}\text { Post } \\
\text { reform } \\
2013\end{array}$ & $\begin{array}{l}\text { Prior } \\
\text { reform } \\
2008\end{array}$ & $\begin{array}{l}\text { Post } \\
\text { reform } \\
2012\end{array}$ & $\begin{array}{l}\text { Post } \\
\text { reform } \\
2013\end{array}$ & $\begin{array}{l}\text { Prior } \\
\text { reform } \\
2008\end{array}$ & $\begin{array}{l}\text { Post } \\
\text { reform } \\
2012\end{array}$ & $\begin{array}{l}\text { Post } \\
\text { reform } \\
2013\end{array}$ & $\begin{array}{l}\text { Prior } \\
\text { reform } \\
2008\end{array}$ & $\begin{array}{l}\text { Post } \\
\text { reform } \\
2012\end{array}$ & $\begin{array}{l}\text { Post } \\
\text { reform } \\
2013\end{array}$ \\
\hline $\begin{array}{l}\text { Disagree } \\
\text { strongly/ } \\
\text { slightly }\end{array}$ & 1.8 & 11.6 & 6.3 & 1.5 & 8.3 & 6.1 & 46.4 & 55.1 & 44.8 & 11.8 & 19,3 & 15.4 \\
\hline Neutral & 2.1 & 6.4 & 3.0 & 4.5 & 7.4 & 2.2 & 6.5 & 5.0 & 4.5 & 10.3 & 9.9 & 7.3 \\
\hline $\begin{array}{l}\text { Agree slightly/ } \\
\text { strongly }\end{array}$ & 95.6 & 81.6 & 90.2 & 91.1 & 80.8 & 87.1 & 46.7 & 39.6 & 50.4 & 76.3 & 68.0 & 76.6 \\
\hline $\begin{array}{l}\text { Not applicable/ } \\
\text { no opinion }\end{array}$ & 0.5 & 0.4 & 0.5 & 2.9 & 3.5 & 4.6 & 0.4 & 0,3 & 0.3 & 1.6 & 2.8 & 0.7 \\
\hline
\end{tabular}




\begin{tabular}{|c|c|c|c|c|}
\hline \multirow{2}{*}{ Item } & \multicolumn{2}{|c|}{ t-value } & \multicolumn{2}{|c|}{ Significance level } \\
\hline & 2012 & 2013 & 2012 & 2013 \\
\hline I would feel safe as a customer here & 16.4 & 8.06 & $\mathrm{P}<0.01$ & $\mathrm{P}<0.01$ \\
\hline Dispensing errors are handled in a correct way at this pharmacy & 11.4 & 6,68 & $\mathrm{P}<0.01$ & $\mathrm{P}<0.01$ \\
\hline The staff level at this pharmacy is sufficient to handle the number of customers & 5.4 & 0,90 & $P<0.01$ & ns \\
\hline The management of this pharmacy supports me in my daily work & 5.2 & 1,51 & $P<0.01$ & ns \\
\hline
\end{tabular}

For two items there was a significant decrease in both studies carried out after, as compared to before the reform (see Table 3). These items are "I would feel safe as a customer here" and "Dispensing errors are handled in a correct way at this pharmacy". For the two other items "The staff level at this pharmacy is sufficient to handle the number of customers" and "The management of this pharmacy supports me in my daily work", a significant change was present in the study carried out in 2012, but not in the latter study carried out in 2013.

\section{DISCUSSION}

The extent of the comparison of the studies is limited, although carry strength, since all three studies are large. The SAQ study includes a total population; i.e. all pharmacy staff, while the Agency studies are carried out on large samples.

The comparison of the two items representing the dimension Safety Climate in SAQ, demonstrate significant differences in both studies performed after, as compared to before, the reregulation, which could be attributed to less favourable conditions in pharmacies. In the SAQ study the Swedish community pharmacies demonstrated high scores for this dimension, as compared to health care settings in other countries. ${ }^{20}$ One possible explanation then was that the state-owned monopoly for a considerable time had put great effort into quality management. Thus good quality awareness, with a focus on safety issues in these pharmacies, was established. ${ }^{24}$ Obviously a change has occurred in the transition from monopoly to diversity within the Swedish pharmacy market. This might be a consequence of the main focus of the transformation of the Swedish pharmacy system being on availability to pharmacies and demonopolization of ownership- and not on safety issues.

A more pronounced interest in patient safety and quality issues in the regulatory change process might have brought about another result. Also, the pharmacy owners' focus on profitability rather than patient care probably has an impact on the transition outcome. According to one of the Agency reports, many staff members believe that attention has moved from pharmacy to profit concerns e.g. sale campaigns; and $45 \%$ report having too little time for dispensing, one reason being the management's demand for selling of additional products. ${ }^{6}$ This might contribute to less time and interest spent on quality management.

The other two items are about working conditions and these results do not demonstrate any significant changes in the latest survey even though both items demonstrated significantly lower values in the first
Agency survey. The reregulation brought about a major change since many pharmacy staff had to work in new organizations with new goals and managements. Changes on both the political, i.e. changes in the system, and the organizational level can have constituted stressors for staff ${ }^{25}$ - which could explain this variation. Working conditions are settling over time and also, the staff is getting used to their change in circumstances.

The results imply that there is a change in the attitude of staff towards patient safety issues in pharmacies. One could ask if this possibly could have been anticipated and prevented. In the impact assessment that was carried out by the investigation preceding the reregulation there are few comments on safety issues. ${ }^{2}$ No risk analysis was performed and no reflections regarding the impact of the reregulation on these matters are to be found. With such an extensive and rapid change in the healthcare sector, there should be concerns about patient safety. If a comprehensive impact assessment had been carried out, it might have predicted the problems and difficulties that the change could entail. Re-organizing, as in this case, an entire sector within health care, obviously has effects on staff and, consequently, on patients in community pharmacies.

\section{Limitations}

The studies were carried out by different parties and had different frames for sample selections, where one study comprised all staff in Swedish community pharmacies and the other a sample of union members. However, the method, an electronically submitted questionnaire, was the same.

\section{CONCLUSIONS}

Political reforms in healthcare can have an impact on patient safety. The comparison carried out in this study indicates a negative effect in Swedish community pharmacies on safety and quality, after a reregulation of the pharmacy market. The possible effects of healthcare reforms should be assessed before implementation, in order to counteract a conceivable decline in factors including patient safety and working conditions.

\section{ACKNOWLEDGMENTS}

Anna Eriksson at the Swedish Agency for Public Management is acknowledged for her generosity in sharing data, and interesting discussions.

Members of the Social Pharmacy Group, Uppsala University are gratefully acknowledged for their contributions to this paper. 


\section{CONFLICT OF INTEREST}

There are no conflicts of interest associated with this manuscript, and there has been no external financial support.

\section{TENDENCIAS EN LA PERCEPCIÓN DEL PERSONAL DE LAS FARMACIAS SOBRE LA SEGURIDAD DE LOS PACIENTES EN LAS FARMACIAS COMUNITARIAS SUECAS DESPUÉS DE LA RE-REGULACIÓN DE LAS CONDICIONES}

\section{RESUMEN}

Antecedentes: Todos los cambios en la regulación de las farmacias tienen un impacto en el trabajo realizado in las farmacias y también en la seguridad del paciente, independientemente de si esta era la intención o no. Objetivo: Comparar el nerviosismo sobre algunos aspectos de la seguridad del paciente y de la calidad en farmacias comunitarias entes y después de los cambios de reglamentación en el mercado sueco de farmacias comunitarias.
Métodos: Unos cuestionarios que se dirigían an personal de las farmacias antes y después de los cambios en la regulación (en 2008, 2011/12, y 2012/13

respectivamente) usaban cuatro ítems idénticos, lo que permitió la comparación de algunos aspectos.

Resultados: Los cuatro ítems demostraron un descenso significativo en la primera encuesta después de los cambios comparados con antes. En la segunda encuesta se encontraron cambios significativos en los dos ítems que representaban el clima de seguridad, mientras que los ítems que representaban el clima de equipo y la gestión no mostraron diferencias significativas.

Conclusiones: La comparación realizada en este estudio indica un efecto negativo en los problemas de seguridad y de calidad de las farmacias comunitarias suecas, según el personal de la farmacia. Se recomienda que se evalúen los posibles efectos de las reformas sanitarias antes de su implantación, para prevenir disminución en factores como la seguridad de los pacientes y las condiciones laborales.

Palabras clave: Farmacias; Regulación Gubernamental; Servicios de farmacias comunitarias; Seguridad del Paciente; Actitud del Personal de Salud; Suecia

1. Vogler S, Arts D, Sandberger K. Impact of pharmacy deregulation and regulation in European countries. Vienna: Gesundheit Österreich; 2012.

2. Ministry of Health and Social Affairs. Swedish Government Official Report 2008:4 Omreglering av apoteksmarknaden. Huvudbetänkande av Apoteksmarknadsutredningen [SOU 2008:4 Reregulation of the pharmacy market. Main report of the Pharmacy Market Commission]. Stockholm: Statens offentliga utredningar; 2008.

3. The Swedish Riksdag. Government Bill 2008/2009:145. Available from: http://www.riksdagen.se/sv/DokumentLagar/Forslag/Propositioner-och-skrivelser/Omreglering-av-apoteksmarknade GW03145/ (accessed 2014 July 15).

4. Medical Products Agency. Listed authorized pharmacies January 17 2014. Available from: http://www.lakemedelsverket.se/malgrupp/Apotek--handel/Apotek/-Tillstand-for-apotek (accessed 2014 March 16).

5. Vårdanalys [The Swedish Agency for Health and Care Services Analysis]. Report 2014:3. Låt den rätte komma in [Let the right one get in]. Stockholm: Vårdanalys; 2014.

6. Statskontoret [Swedish Agency for Public Management]. 2013:7 En omreglerad apoteksmarknad - Slurapport [A reregulated pharmacy market - Final Report]. Stockholm: E-print AB; 2013.

7. Cipolle RJ, Strand LM, Morley PC. Pharmaceutical care practice. The patient-centered approach to medication management. 3rd ed. New York: McGraw Hill Medical, 2012.

8. Medical Products Agency. Läkemedelsansvarig [Pharmacist responsible for upholding quality requirements in pharmacies]. Available from: http://www.lakemedelsverket.se/malgrupp/Apotek--handel/Apotek/Lakemedelsansvarig (accessed 2014 July 15).

9. Medical Products Agency. Läkemedelsverkets föreskrifter om ansökan om tillstånd att bedriva öppenvårdsapotek [Regulations on applications for operating community pharmacies] (LVFS 2009:8) Available from: http://www.lakemedelsverket.se/upload/lvfs/konsoliderade/LVFS 20098 konsoliderad tom 2010 11.pdf (accessed 2014 July 15).

10. The Swedish Riksdag. Svensk författningssamling [Swedish statute book]. Lag om handel med Läkemedel [Act on trade with pharmaceuticals] (SFS 2009:366). Available from: http://www.riksdagen.se/sv/DokumentLagar/Lagar/Svenskforfattningssamling/Lag-2009366-om-handel-med-I sfs-2009-366/?bet=2009:366 (accessed 2014 July 15).

11. Schafheutle EI, Seston EM, Hassell K. Factors influencing pharmacist performance: A review of the peer-reviewed literature. Health Policy. 2011;102(2-3):178-192. doi: 10.1016/j.healthpol.2011.06.004

12. Malone DC, Abarca J, Skrepnek GH, Murphy JE, Armstrong EP, Grizzie AJ, Rehfeld RA, Woosley RL. Pharmacist workload and pharmacy characteristics associated with the dispensing of potentially clinically important drug-drug interactions. Med Care. 2007;45(5):456-462.

13. Rupp MT, DeYoung M, Schondelmeyer SW. Prescribing problems and pharmacist interventions in community practice. Med Care. 1992;30(10):926-940.

14. Hawksworth GM, Corlett AJ, Wright DJ, Chrystyn H. Clinical pharmacy interventions by community pharmacists during the dispensing process. Br J Clin Pharmacol. 1999;47(6):695-700.

15. Aschcroft DM, Quinlan P, Blenkinsopp A. Prospective study of the incidence, nature and causes of dispensing errors in community pharmacies. Pharmacoepidemiol Drug Saf. 2005;14(5):327-332.

16. Knudsen $\mathrm{P}$, Herborg $\mathrm{H}$, Mortensen AR, Knudsen M, Hellebek A. Preventing medication errors in community pharmacy: Frequency and seriousness of medication errors. Qual Saf Health Care. 2007;16(4):291-296. 
17. Peterson GM, Wu MS, Bergin JK. Pharmacists' attitudes towards dispensing errors: their causes and prevention. J Clin Pharm Ther. 1999;24(1):57-71.

18. Grasha AF. Misconceptions about pharmacy workload. Can Pharm J. 2001;134(3):26-35.

19. Farmaciförbundets Arbetsmiljöbarometer 2011; [Report on working environment - by the Farmaciförbundet union]. Stockholm: Farmaciförbundet; 2011.

20. Norden-Hägg A, Sexton JB, Kälvemark-Sporrong S, Ring L, Kettis-Lindblad Å. Assessing safety culture in pharmacies: The psychometric validation of the safety attitudes questionnaire (SAQ) in a national sample of community pharmacies in Sweden. BMC Clin Pharmacol. 2010;10:8. doi: 10.1186/1472-6904-10-8

21. Nordén-Hägg A, Kälvemark Sporrong S, Kettis Lindblad A. Exploring the relationship between safety culture and reported dispensing errors in a large sample of Swedish community pharmacies. BMC Pharmacol Toxicol. 2012;13:4. doi: 10.1186/2050-6511-13-4

22. Sexton JB, Helmreich RL, Neilands TB, Rowan K, Vella K, Boyden J, Roberts PR, Thomas EJ. The safety attitudes questionnaire: Psychometric properties, benchmarking data, and emerging research. BMC Health Serv Res. 2006;6:44.

23. Statskontoret [Swedish Agency for Public Management]. 2012:19 En omreglerad apoteksmarknad - delrapport 2 [2012:19 A re-regulated pharmacy market - Interim Report 2]. Stockholm: E-print AB; 2012.

24. Nordén-Hägg A. 2010. Failure-Free Pharmacies? An Exploration of Dispensing Errors and Safety Culture in Swedish Community Pharmacies. Acta Universitatis Upsaliensis. Digital Comprehensive Summaries of Uppsala Dissertations from the Faculty of Pharmacy 126, 88 pp. Uppsala. ISBN 978-91-554-7876-6.

25. Arnetz BB. Stress - Why Managers Should Care. In: Arnetz BB, Ekman R, editors. Stress in Health and Disease. Weinheim: Wiley-VCH Verlag \& Co.KGaA; 2006. 